Potravinarstvo Slovak Journal of Food Sciences

vol. 15, 2021, p. 318-329

https://doi.org/10.5219/1578

Received: 12 February 2021. Accepted: 12 April 2021.

Available online: 28 April 2021 at www.potravinarstvo.com

(C) 2021 Potravinarstvo Slovak Journal of Food Sciences, License: CC BY 4.0

ISSN 1337-0960 (online)

\title{
THE EFFECT OF DRY DEMINERALIZED WHEY (DDW) AND COCONUT OIL ON THE RHEOLOGICAL CHARACTERISTICS OF THE LEGUME BUTTER
}

\author{
Igor Stadnyk, Volodymyr Piddubnuy, Mykhail Kravchenko, Larysa Rybchuk, \\ Stepan Balaban, Taisia Veselovska
}

\begin{abstract}
This article reveals the possibility of using legume butter to obtain a new combined product of increased quality. The technology of model compositions of finishing semi-finished products, in particular, confectionery legume butter with DDW, has been developed. The results of a study on optimizing the recipe composition of finishing semi-finished products made it possible to develop this technology of multifunctional confectionery butter with the desired (specified) organoleptic and structural and mechanical properties. The analysis of the formation of the structure of legume butter of oppositely directed processes in the enzymatic destruction of the residual cellular structure and spontaneous aggregation of protein particles into the spatial structure due to gradual dehydration of the system was carried out. It is noted that sugar plays the role of a plasticizer, reducing the rate of gelatinization of starch while reducing the viscosity peak. The use of dry demineralized whey (DDW) in legume butter technologies contributes to the formation of a stronger structure of the protein component and the development of a spatial structure, which gives it certain structural and mechanical properties. Three main directions of technological use of confectionery butter were established, which are based on structural characteristics of consistency: 1 - confectionery butter used to cover confectionery products and as a layer for them (CP - Confectionery Products), where the main indicator of consistency is extensibility; 2 - confectionery butter used for making flowers, as a decorative element for flour confectionery (SC - Sugar Confectionery)), where the main indicator of consistency is an equivalent ratio of extensibility and forming ability; 3 - confectionery butter used for modeling shaped products, as a decorative element for flour confectionery products, where the main indicator of consistency is the forming ability. The results of studies of the rheological characteristics of legume butter with dry demineralized whey (DDW) and coconut oil are presented. It was ascertained that DDW and coconut oil lead to changes in the state of legume butter, changing the values of rheological characteristics. The rational content of DDW and coconut oil in the composition of legume butter while ensuring high functional and technological properties was proved. The optimal ratios of components of the developed legume butter were mathematically grounded.
\end{abstract}

Keywords: legume butter; dry whey powder; bean; rheological properties; modeling

\section{INTRODUCTION}

Food products significantly affect human health throughout life and therefore pose a significant potential danger. WHO data show (WHO, 2015) that more than $80 \%$ of all diseases of adults and children are more or less associated with eating disorders (cardiovascular diseases, type 2 diabetes mellitus (DM), osteoporosis, etc.). The nutritional value of confectionery products (Nazarova and Chuprina, 2018; Dzjuba et al., 2017) is and remains an existing complex of carbohydrates, proteins, fats, minerals, vitamins, etc. Therefore, when researching and implementing new technologies for confectionery and semi-finished products, it is still necessary to improve the range of children's and dietary food. The solution of problems recently is based on the addition of fillers of the recipe composition to confectionery butter masses, while the product is enriched with biologically active substances.
After all, a necessary complex of substances for the human body, butter has a multifunctional use in confectionery production.

For the creation of new types of food products of increased biological value, there is considerable interest in non-traditional and local kinds of raw materials such as plant-based products, which are cheaper and less laborintensive during production. We are aware (Diakonova, 2006) that raw materials of vegetable origin are divided into several groups: fruit and vegetable products, vegetable products, leguminous products, starch products. First of all, such requirements are met by cereals and legumes.

They have the features necessary for improvement: they are harmless to the human body, generally available, cheap, and most importantly, they are a natural source of finished products enriched with proteins, fats, dietary fiber, 
vitamins, minerals, polyphenolic compounds, and other biologically active substances. Rational use of vegetable raw materials and the creation of various forms of food protein (protein flour, concentrates, texturates, isolates) on its basis is a promising direction for solving the problem of reducing protein deficiency.

Modern technologies of the confectionery industry enable the creation of products with a variety of taste characteristics, smells, textures, shapes, which attract the attention of consumers and increase demand. Recently, special attention has been paid to the production of legumes, which are of great importance for improving the supply of food to the population. Currently, a large number of samples of the leguminous collection, including beans, have been collected. The study of some biochemical parameters of these samples (Ryabchenko and Ulyanchenko, 2008; Balia, 2011) is of great theoretical and practical value.

Vegetable protein is the most important component of food and feed resources, the use of which significantly affects the state of human health, their well-being, duration, and standard of living. This has become especially important nowadays when there is a considerable increase in the population of our planet, which leads to protein starvation in some countries. At the end of the twentieth century, the share of vegetable protein (Ryabchenko and Ulyanchenko, 2008) was 70\%, and $30 \%$ accounted for animal protein in the total balance of this product.

Vegetable protein deficiency remains one of the most important problems of our time. In recent years, it has not lost its topicality. Most scientists tend to believe that this period should be the century of leguminous crops, due to which the task of increasing the production of vegetable protein for the needs of animal husbandry and nutrition of the population will be solved. In the conditions of modern agricultural production, replenishing the protein deficit at the expense of their resources is becoming an urgent need.

At the present stage, one of the causes of protein deficiency is the insufficient use of plant resources, in particular representatives of the Fabaceae family of species of the genus Phaseolus vulgaris, which includes about 200 species. However, the high productivity of bean plants is possible only if they are maximally provided with nutrients.

Bean is a valuable high-protein crop (Mazaraki, Kravchenko and Demichkovskaya, 2019), which is widely used in the food industry, medicine, cosmetics. The grain contains substances that contribute to the elimination of radionuclides out of the human body (Skurikhin and Volgarev, 1987). Its importance in the national economy is determined by its high taste and nutritional qualities. Bean products can not only meet human needs for vegetable protein but also diversify the diet, so they are in great demand among the population. The most important nutritional component of bean seeds is proteins (Skurikhin and Volgarev, 1987), which are involved in the most important functions of the body and cannot be replaced by other food substances.

Bean has a high potential yield, which is realized if agrotechnical requirements and recommendations are met. Its average yield in the world is about $0.07 \mathrm{t}^{\mathrm{h} \mathrm{ha}^{-1}}$, and under optimal conditions, it reaches $3.0-4.5$ t.ha ${ }^{-1}$.
Especially as a food item (Mazaraki, Kravchenko and Demichkovskaya, 2019; Lukomets, 2012), beans are in high demand. Its grain contains up to $32 \%$ protein, which is close in nutritional value to animal proteins. In addition to protein, the grain contains $41.0-54.6 \%$ carbohydrates, $0.4-3.6 \%$ fat, $2.2-6.6 \%$ fiber, vitamins E, B1, B2, B6, $\mathrm{C}$, pathogenic acid, riboflavin, minerals.

A special feature of the bean is its rich mineral composition which are iron (up to $8 \%$ ), calcium, phosphorus, potassium, sodium, magnesium, iodine, fiber, citric acid, ash substances. As confirmed by these data, the bean is a food product that contains almost all the substances necessary for normal human nutrition, which puts it among dietary products.

In modern society, the industrialization and globalization of food production, as well as advertising in the media, are increasingly affecting the quality of food, so it is important not to weaken the role of scientific developments and findings of specialists. The bean has long been a traditional crop in Ukraine, but it is not widely distributed. Therefore, further development of the scientific foundations of the technology of its use in the confectionery industry is an important scientific problem.

\section{Analysis of model approximations of medium types}

Given the current market needs, legumes are playing an increasingly important role in the food development process. Some of them, for example, soy (Avdeyeva, 2003; Lukomets, 2012) have long been massively used in the manufacturing of products with combined meat and vegetable composition as a structural and protein additive. Similar studies are also conducted for other legumes bean, pea, chickpea. The initial assessment of the possibility of using pea and bean butter for organoleptic parameters was carried out in the works (Avdeyeva, 2003). Samples with the addition of beans had high taste properties, which is an important component for semifinished products.

Various botanical varieties of the white and red bean are widely used in confectionery production, especially in Japan, China, and Korea. Quite clearly, their works (Honda et al., 2020; Li et al., 2017) revealed a sweet bean butter made by boiling sugar with beans. It is widely used for gluing cakes, pastries, cookies, as a layer for desserts and flour confectionery, for making sweets, bars and as a plastic mass for making flowers and modeling shaped decorative elements. These developed technologies make it possible to obtain confectionery bean butter of high biological and nutritional value, but it has rather low organoleptic characteristics due to the inherent specific taste and aroma of legumes.

At the same time, to solve the relevant technological problems of bakery and confectionery production, certain types of specialized fat products are being developed, which allows optimizing the manufacturing technology of products of increased nutritional value and storage stability. To ensure the appropriate functional orientation, searches are underway to include valuable additional ingredients in the formula, in particular those with a balanced fatty acid composition, a reduced content of saturated fatty acids, the presence of essential substances of a lipid nature, with a minimum content of cholesterol and trans isomers of fatty acids (Avdeyeva, 2003). The 
scientific direction of technological processes can regulate the nutritional value to a certain extent.

The research (Nazarova and Chuprina, 2018) reveals the choice of process parameters according to the nature of changes in the structure and properties of prescription components in general. We see a direct connection between the importance of nutrition in human life due to the improvement of formula and technological parameters of production. It is known (Kravchenko and Rybchuk, 2018) that legume butter is obtained by boiling sugar and beans in a ratio of $1: 1$. As a result of this interaction, a complex homogeneous system related to coagulation structures is formed. The process of structure formation is determined primarily by the composition and structure of legume cells and the physical condition of polymers.

The author analyzes the comparative characteristics of the chemical composition of individual legumes (Kholodova, 2013). In terms of the amount of essential amino acids per $100 \mathrm{~g}$ of protein, bean dominates over other legumes, except chickpea (Figure 1).

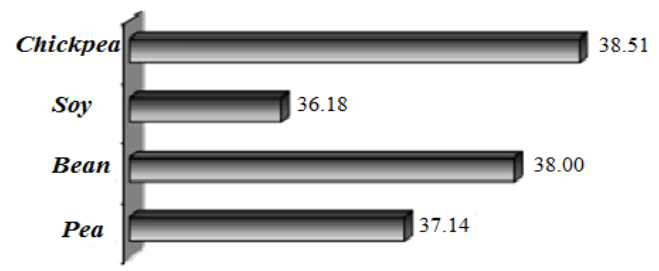

Figure 1 Content of the total amount of essential amino acids in legumes, $\mathrm{g}, 100 \mathrm{~g}^{-1}$ of protein.

That is why scientists have recently increased their interest in legumes as an alternative raw material for the production of pastes. At the initial stage of the interaction of the bean with water, swelling occurs, accompanied by a significant increase in volume and mass. During the cooking stage, the bean peeled from the seed shell undergoes complex physical and chemical changes. This causes the resulting mixture to soften. Temperature parameters have an impact on the course of the process. So, an increase in temperature accelerates the movement of moisture inside the cotyledon of beans. Accordingly, the process of swelling of protein substances and carbohydrates of cell walls is more intense, and the gelatinization of starch, which has already begun, accelerates.

Proteins are denatured during cooking, and the moisture absorbed by them is released and absorbed by the gelatinizing starch. In the process of cooking the cell walls of cotyledons of beans are destroyed under the influence of penetrating moisture and temperature. Pectin substances are most destructed (Avdeyeva, 2003), with an average of $40 \%$, to a lesser extent hemicellulose and structural protein of the cell walls of extensions. Under the pressure of gelatinized starch, cell walls break. This leads to the complete decomposition of the integrity of the cotyledons' shape.

The formation of the structure of legume butter (Kravchenko and Rybchuk, 2019a) is due to the development of two oppositely directed processes. The first one consists of enzymatic destruction of the residual cellular structure, and the second process is a spontaneous aggregation of protein particles into the spatial structure as a result of gradual dehydration of the system. Sugar in this technology plays the role of a plasticizer. By forming binding zones, sugar reduces the rate of starch gelatinization while reducing the peak viscosity.

The use of dry demineralized whey (DDW) is considered in sufficient detail in our work (Kozlova, 2014). Therefore, due to its high moisture-binding and moistureretaining ability, it will contribute to the formation of a stronger structure of its protein component in legume butter technologies due to the emergence and development of a spatial structure. As a result of thermal denaturation and coagulation of proteins dissolved in the continuous phase of the dispersion medium, under the appearance of stronger hydrogen bonds, it gives the framework a static shear strength. This allows giving certain structural and mechanical properties to the legume butter.

According to the results of previous studies, it was found (Kravchenko and Rybchuk, 2019b; Stadnyk et al., 2020) that DDW at a concentration of $10-30 \%$ improves the rheological characteristics of legume butter. Increasing the forming capacity indicators gives the butter certain functional and technological properties. Certain concentrations help to "mask" the taste and aroma of legumes. Also, a harmonious taste and aroma composition are created with improved organoleptic characteristics of legume butter. This butter can be used in confectionery products, as finishing semi-finished products.

However, an increase in the concentration of DDW in legume butter technologies contributes to an increase in the adhesive and cohesive strength, which makes it difficult to work with butter. Bean butter, in comparison with sugar one, is characterized by lower strength, so to reduce the adhesive-cohesive strength, it is advisable to consider the fat component, which at a temperature of $21{ }^{\circ} \mathrm{C}$ has a solid consistency. This is due to certain crystallization characteristics, which are determined by the composition of fatty acids. As it is known (Kravchenko, and Rybchuk, 2019a; Stadnyk et al., 2019), fats dominated by saturated fatty acid glycerides have a higher hardness. According to the results of physical and chemical properties, the optimal characteristics were determined in coconut oil. By chemical composition, coconut oil is characterized by a high content of saturated fatty acids, in particular lauric and myristic, as well as a small number of volatile acids, namely caprylic and caproic. Coconut oil has high oxidation resistance, this is because $90 \%$ of fatty acids are saturated. Therefore, the choice of coconut oil in the formula of legume butter with DDW is explained by acceptable physical and chemical, and organoleptic characteristics, which will help to improve the functional and technological properties of confectionery butter. The consistency and taste of the product depending on the structural and mechanical characteristics of legume butter. Therefore, when manufacturing products, it is necessary to choose the optimal composition of ingredients according to the recipe.

Based on partial research conducted by various authors and our specialists, it was decided to develop a technology for model compositions of finishing semi-finished products, in particular, confectionery legume butter with DDW and additional recipe components. The results of a study on optimizing the formula of finishing semi-finished 
products make it possible to develop this technology of multifunctional confectionery butter with the desired (specified) organoleptic and structural-mechanical properties.

We have proposed 3 main directions of technological use of the developed confectionery butter, which are based on the structural characteristics of the consistency. The first category includes confectionery butter used to cover confectionery products and layer them (CPC). The main indicator of consistency is extensibility.

The second category includes confectionery butter used for making flowers as a decorative element for flour confectionery products (CPD). The main indicator of consistency is an equivalent ratio of extensibility and forming ability.

The third one consists of confectionery butter used for figured products modeling, as a decorative element for flour confectionery products (FPM). The main indicator of consistency is the forming ability.

\section{Scientific hypothesis}

The perspective for using white bean of the "Mavka" cultivar with the optimal amount of DDW additive and coconut oil as a possible component of determining the effect of the consistency regulator on rheological properties, to improve the functional and technological properties of butter.

\section{MATERIAL AND METHODOLOGY. Samples}

The work uses the components that are required according to the recipe in the production of this system of bean pastes with the relevant current regulations documentation: white food beans variety "Mavka"; Dry demineralized whey; Coconut oil; Granulated sugar.

Dry demineralized whey, made from whey with a $90 \%$ level of demineralization following TU U 15.5-00413890089:2014, white food beans of the Mavka variety. Bean variety belongs to the group of early, yield-resistant to various diseases, has high taste properties, oval-cylindrical shape, smooth. Manufacturer Odessa, TM "Spring". Coconut oil was bought in a store in Kyiv. Manufacturer: Green Volley Oils. India. Packaged by PKF Aroza LLC, Ukraine, Kyiv region. Granulated sugar - GOST 21-94 Rivne, Ukraine, Factory of confectionery jewelry "Decoration" - TU U 10.8-40570177-001:2016.

\section{Chemicals}

For the first stage of cooking, water (chemical formula $\mathrm{H}_{2} \mathrm{O}$ ) was used for soaking, washing, cooking. Water corresponds to the national standard TU U 2.14-0051232098:2007.

\section{Instruments}

Elastic-elastic and plastic-viscous properties were determined on a plane-parallel elastoplastomer of Tolstoy, made in Russia. Adhesion and cohesion strength was performed on a dynamometer MIG1.3, producer limited liability company ITM KharkivThe temperature was measured with a thermometer TLS Ukrainian manufacturer "Glass Device", which is designed to accurately measure temperature. The obtained results were statistically processed using the standard Microsoft Office software package.

\section{LaboratoryMethods}

Sampling was performed according to DSTU 4803 (2013), Organoleptic evaluation "Descriptive (qualitative) method of profile analysis" GOST 5897-90 (1992).

\section{Method of researches of rheological characteristics of model compositions}

The method of rheological characteristics is based on the construction of a graph of the yield curve of the prototype under the action of the applied shear stress (under loading and unloading). It is used to establish the elastic-elastic and plastic-viscous properties of the test samples (Tolstoy's plane-parallel elastoplastometer). During the study of the rheological characteristics of the samples, a fixed load of $65 \mathrm{~g}$ was selected at the same temperature $\left(+6{ }^{\circ} \mathrm{C}\right)$ and sample height $(7 \mathrm{~mm})$. The separation of the total deformation into inverse and irreversible was carried out by a simplified method of extrapolation of the linear section of deformation to the intersection with the y-axis $\gamma$ $=\mathrm{f}(\mathrm{t})$ (proposed by Rebinder). This makes it possible to determine the relative deformation, shear stress, modulus of elasticity, modulus of elasticity, plastic viscosity according to known formulas. Adhesion-cohesive strength - by the method of normal separation.

\section{Research of organoleptic characteristics of model compositions}

To determine them, the method of developing organoleptic scales was used: indicators of appearance, taste, smell, consistency, molding ability. It is used when the composition of the sample is known, and the approximate number of them changes the characteristics. This makes it possible to bring the composition of the components as close as possible to the composition of the samples. following the distribution of weights, identified areas of technological use of confectionery pastes. The ability to form and the degree of detection of this indicator determine the manufacturability of confectionery pastes. For PKV the ratio of weights in terms of consistency is $0.1: 0.1: 0.7: 0.1$, for $\mathrm{VCC}-0.2: 0.2: 0.3: 0.3$, for IRF $0.3: 0.2: 0.2: 0.3$. The weighting factor of this indicator concerning the weighting factor of the consistency and determines the direction of technological use of confectionery pastes, which is for PKV 0.4:0.2, VTSK 0.3:0.3, IRF - 0.2:0.4.

Weights were determined by an expert method under the following conditions (1):

$$
\sum_{i=1}^{n} m_{i j}=1
$$

Where:

$m_{i j}$ is the weighting factor of the $i$-th indicator of the $j$-th group ( $\mathrm{m}$ and $>0$ ); $\mathrm{n}$ is the number of product quality indicators. 
Table 1 Score scale of organoleptic quality assessment of model compositions of legume butter with DDW.

\begin{tabular}{|c|c|c|c|c|c|c|c|c|c|}
\hline \multirow{2}{*}{$\begin{array}{l}\text { Complex } \\
\text { indicators }\end{array}$} & \multicolumn{3}{|c|}{$\begin{array}{l}\text { Weighting } \\
\text { coefficient }\end{array}$} & \multirow{2}{*}{$\begin{array}{l}\text { Individual } \\
\text { indicators }\end{array}$} & \multicolumn{3}{|c|}{$\begin{array}{l}\text { Weighting } \\
\text { coefficient }\end{array}$} & \multirow[t]{2}{*}{ Characteristics } & \multirow{2}{*}{$\begin{array}{c}\text { Quality level, } \\
\text { points }\end{array}$} \\
\hline & CPC & CPD & FPM & & CPC & CPD & FPM & & \\
\hline \multirow{9}{*}{ Appearance } & \multirow{9}{*}{0.2} & \multirow{9}{*}{0.2} & \multirow{9}{*}{0.2} & \multirow{5}{*}{ Color intensity } & \multirow{5}{*}{0.9} & \multirow{5}{*}{0.1} & \multirow{5}{*}{0.9} & $\begin{array}{l}\text { Strong } \\
\text { Weak }\end{array}$ & $\begin{array}{l}5 \\
4\end{array}$ \\
\hline & & & & & & & & Noticeable & 3 \\
\hline & & & & & & & & Barely noticeable & 2 \\
\hline & & & & & & & & Absent & 1 \\
\hline & & & & & & & & Strong & 5 \\
\hline & & & & \multirow{4}{*}{ Transparency } & \multirow{4}{*}{0.1} & \multirow{4}{*}{0.9} & & Weak & 4 \\
\hline & & & & & & & 0.1 & Noticeable & 3 \\
\hline & & & & & & & & Barely noticeable & 2 \\
\hline & & & & & & & & Absent & 1 \\
\hline & & & & & & & & Strong & 1 \\
\hline & & & & Distinctness & & & & Moderate & 2 \\
\hline & & & & (of the bean taste & 0.4 & 0.4 & 0.4 & Weak & 3 \\
\hline & & & & $\begin{array}{c}\text { and } \\
\text { smell }\end{array}$ & & & & Barely noticeable & 4 \\
\hline & & & & & & & & Absent & 5 \\
\hline & & & & & & & & Strong & 1 \\
\hline & & & & Saturation & & & & Moderate & 2 \\
\hline & & & & (of the bean taste & 0.3 & 0.3 & 0.3 & Weak & 3 \\
\hline Taste and smell & 0.2 & 0.2 & 0.2 & $\begin{array}{l}\text { and } \\
\text { smell) }\end{array}$ & & & & Barely noticeable & 4 \\
\hline & & & & Smeni) & & & & Absent & 5 \\
\hline & & & & & & & & Excellent & 5 \\
\hline & & & & & & & & Good & 4 \\
\hline & & & & Balance & & & & Satisfactory & 3 \\
\hline & & & & & & & & Unsatisfactory & 2 \\
\hline & & & & & & & & $\mathrm{Bad}$ & 1 \\
\hline & & & & - & 1.0 & 1.0 & 1.0 & - & - \\
\hline & & & & & & & & $\begin{array}{l}\text { Moderately } \\
\text { compacted }\end{array}$ & 5 \\
\hline & & & & Density strength & 01 & 02 & 03 & Compacted & 4 \\
\hline & & & & & & 0.2 & 0.3 & Dense & 3 \\
\hline & & & & & & & & Very dense & 2 \\
\hline & & & & & & & & Solid & 1 \\
\hline & & & & & & & & Average & 5 \\
\hline & & & & & & & & Moderate & 4 \\
\hline & & & & Stickiness & 0.1 & 0.3 & 0.3 & Satisfactory & 3 \\
\hline & & & & & & & & High & 2 \\
\hline Consistence & 0.4 & 03 & 02 & & & & & Too high & 1 \\
\hline Cuisialctice & & & & & & & & Moderately soft & 5 \\
\hline & & & & & & & & Soft & 4 \\
\hline & & & & Softness & 0.1 & 0.2 & 0.2 & Moderately solid & 3 \\
\hline & & & & & & & & Solid & 2 \\
\hline & & & & & & & & Too solid & 1 \\
\hline & & & & & & & & Excellent & 5 \\
\hline & & & & & & & & Good & 4 \\
\hline & & & & Extensibility & 0.7 & 0.3 & 0.2 & Average & 3 \\
\hline & & & & & & & & Weak & 2 \\
\hline & & & & & & & & Very weak & 1 \\
\hline & & & & - & 1.0 & 1.0 & 1.0 & - & - \\
\hline & & & & & & & & Excellent & 5 \\
\hline & & & & & & & & Good & 4 \\
\hline Forming ability & 02 & 03 & 0.4 & Detection degree & 1.0 & 1.0 & 1.0 & Satisfactory & 3 \\
\hline & & & & & & & & Unsatisfactory & 2 \\
\hline & & & & & & & & $\mathrm{Bad}$ & 1 \\
\hline & & & & - & 1.0 & 1.0 & 1.0 & 1.0 & - \\
\hline
\end{tabular}

The weighting factor mij was determined by the formula (2):

$$
m_{i j}=\frac{m_{i j c p}}{\sum_{i=1}^{n} m_{i j c p}}
$$

Where:

$\mathrm{m}_{\mathrm{ij}} \mathrm{sr}$ is the arithmetic mean of the experts' assessments of the $\mathrm{i}$-th quality indicator of the $\mathrm{j}$-th group. 
The average value of mijsr was determined by the formula (3):

$$
m_{i j c p}=\frac{1}{N} \sum_{z=1}^{N} m_{i j z},(\mathrm{z}=1,2,3 \ldots \mathrm{N})
$$

Where:

$\mathrm{N}$ is the number of experts; $\mathrm{mi}_{\mathrm{jz}}$ - assessment of the $\mathrm{i}$-th quality indicator of the $\mathrm{j}$-th group, given by the $\mathrm{z}$-th expert $(\mathrm{z}=1,2,3 \ldots \mathrm{N})$.

The results of the analysis are presented in Table 1.

\section{Description of the Experiment}

Bean paste was prepared according to the developed technology. In the model compositions of the bean, pastes used white bean puree, obtained by boiling sugar and beans in a ratio of $1: 1$, resulting in a complex homogeneous system related to coagulation structures.
Since the beans are dried, they must be soaked in water for at least twelve hours. During this time, it will increase in size, and after soaking and washing the beans become lighter. Drain this water, fill the beans with fresh water and bring it to a boil. As soon as the foam appears on the surface of the water, drain the first water and fill the beans with fresh water so that it would completely cover the beans with water. Boil beans in this water until fully cooked. This time takes about two hours. If necessary, add water to the beans. The readiness of the beans was checked: first, by breaking some beans, and secondly, by rubbing between the fingers of one or two beans. Drain the remaining water from the beans, wash it once again in running water. Pouring back into the pan, cover with granulated sugar 1:1, and continue to cook our dish over high heat with constant stirring. You do not need to add water. A fully described process is presented in Table 2.

Table 2 Technological system of making legume butter.

\begin{tabular}{|c|c|c|c|}
\hline Subsystem & $\begin{array}{c}\text { Subsystem } \\
\text { name }\end{array}$ & $\begin{array}{c}\text { Subsystem } \\
\text { tasks }\end{array}$ & Technological operations and parameters \\
\hline $\mathbf{A}$ & $\begin{array}{l}\text { Mechanical } \\
\text { culinary } \\
\text { processing }\end{array}$ & $\begin{array}{l}\text { Preparation } \\
\text { of } \\
\text { prescription } \\
\text { components }\end{array}$ & $\begin{array}{l}\text { Beans are sorted and cleaned of extraneous impurities, put in the water }\left(\mathrm{t}=15^{\circ} \mathrm{C}\right) \text { in a } \\
\text { ratio of } 1: 2\left(\tau=2.88 .10^{4} \mathrm{c}\right) \text {, and then cleaned from the seed coat. } \\
\text { DDW is dissolved in water }\left(\mathrm{t}=20-21^{\circ} \mathrm{C}\right) \text { and filtered, the hydro module is } 1: 2 \text {. }\end{array}$ \\
\hline B & $\begin{array}{l}\text { Thermal } \\
\text { processing }\end{array}$ & $\begin{array}{c}\text { Formation of } \\
\text { structural and } \\
\text { mechanical } \\
\text { properties }\end{array}$ & $\begin{array}{c}\text { Thermal processing is carried out in several stages: } \\
\text { Stage I - getting beans mashed: } \\
\text { the prepared beans are cooked without draining until tender }\left(\tau=3.6 .10^{4} \mathrm{c},\right. \\
\left.\mathrm{t}=80-85^{\circ} \mathrm{C}\right) \text { and grounded to get a puree of homogeneous consistency. } \\
\text { Stage II - the process of butter plasticization: sugar is added to the resulting puree and } \\
\text { cooked }\left(\tau=3.6 .10^{4} \mathrm{c}, \mathrm{t}=60-65^{\circ} \mathrm{C}\right) \text {. Sugar reduces the rate of starch clusterization, } \\
\text { decreases the peak of viscosity, and gives plasticity to the butter. } \\
\text { Stage III - the introduction of DDW: the prepared DDW is placed into the legume butter } \\
\text { and boiled. }\end{array}$ \\
\hline $\mathbf{C}$ & Cooling & $\begin{array}{l}\text { Obtaining a } \\
\text { homogeneous } \\
\text { plastic mass }\end{array}$ & $\begin{array}{l}\text { The resulting butter is cooled to } \mathrm{t}=20-25^{\circ} \mathrm{C} \text { and mixed with coconut oil until a } \\
\text { homogeneous plastic mass is obtained. }\end{array}$ \\
\hline $\mathbf{D}$ & Infusing & $\begin{array}{l}\text { Getting the } \\
\text { finished } \\
\text { product }\end{array}$ & $\begin{array}{c}\text { Infusing legume butter for }\left(\tau=8.64 .10^{4} \mathrm{c}, \mathrm{t}=1-3^{\circ} \mathrm{C}\right) \text {, which ensures the development } \\
\text { of a constitutional and spatial structure and gives the butter certain functional and } \\
\text { technological properties. }\end{array}$ \\
\hline
\end{tabular}

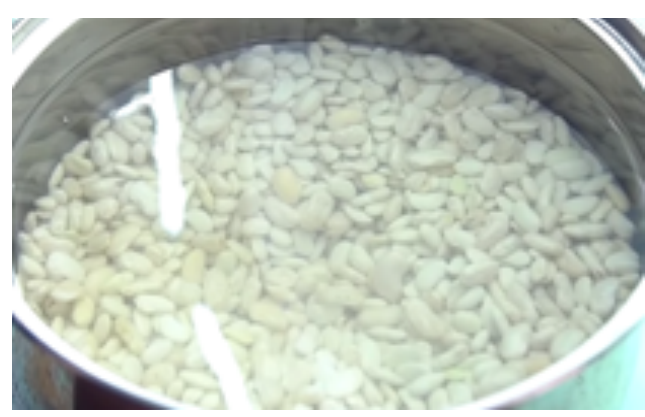

A

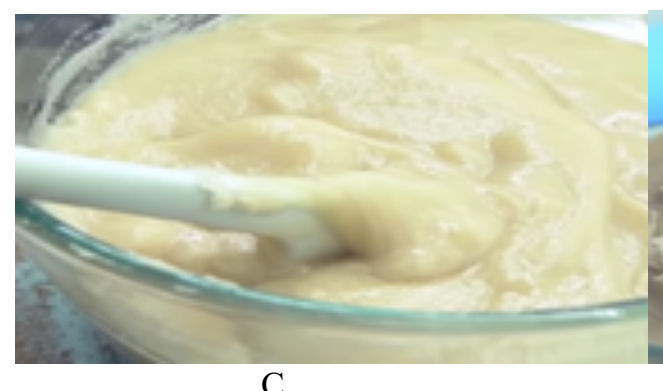

$\mathrm{C}$

Figure 2 Ilustration of procedures making legume butter.

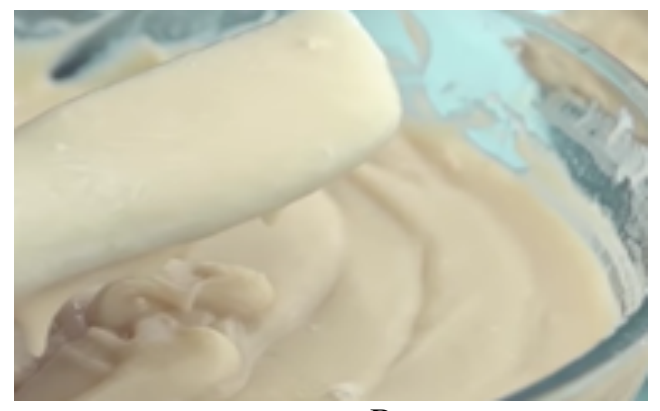

B

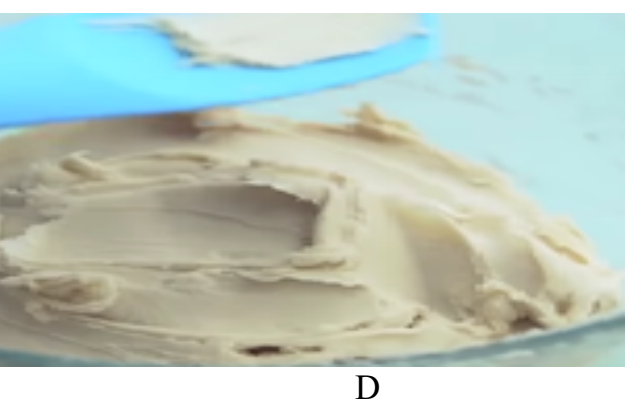


Number of repeated analyses: All measurements of instrument readings were performed 5 times.

Number of experiment replication: The number of repetitions of each experiment to determine one value was also 5 times.

\section{Statistical analysis}

A directed complex of rheological studies was carried out during the development of the recipe composition of bean pastes. They were based on clarifying the role of whey dry demineralized and coconut oil. To do this, the planning and formulation of computational experiments with obtaining the appropriate regression equations.

The dependence of the structural and mechanical properties of the pastes on the content of DDW and coconut oil was constructed by the method of a planned experiment. According to the results of research of organoleptic and structural-mechanical characteristics by the method of the planned experiment the zones of rational concentrations of DDW and coconut oil in the prescription composition of bean pastes according to the direction of their technological use are established. Variable factors, optimization criteria, and the area of the definition of factors (Stadnyk et al., 2018) are defined (Table 3).

According to the experimental planning method, a complete factor experiment of type $2^{1}$ was implemented, with two factors, levels, and intervals of variation of factors (Table 4).

The dependences of the complex rheological index on the content of coconut oil and DDW are described by the following mathematical models:

$\mathrm{Y}_{\mathrm{PKV}}=3.3 \times 10-5 \times 12 \times 22+0.00136 \times 1 \times 22+0.00121 \times 12$ $\mathrm{x} 2-0.0106 \times 12-0.0188 \times 22+0.4423 \times 1+0.6792 \times 2-$ 0.9208
$\mathrm{Y}_{\mathrm{VUK}}=2.92 \times 10-5 \mathrm{x} 12 \times 22-0.000515 \times 1 \times 22-0.000692$ $\mathrm{x} 12 \mathrm{x} 2+0.0131 \mathrm{x} 1 \mathrm{x} 2-0.00091 \mathrm{x} 22+0.00841 \mathrm{x} 1-0.072$ $\mathrm{x} 2+4.886$

$\mathrm{Y}_{\mathrm{MFV}}=3.64 \times 10-5 \times 12 \times 22-0.002 \times 1 \times 22-0.00065 \times 12$ $\mathrm{x} 2+0.0373 \times 1 \times 2-0.0287 \times 22+0.00597 \times 1-0.546 \times 2+$ 4.917

The obtained data made it possible to determine the optimal ratio of the components of the developed bean pastes (Table 5). It is established that all factors are statistically significant. The most statistical value in assessing their mutual influence is their joint use.

The optimal values are selected by rounding the optimized values within the compromise areas, to facilitate the dosing of the prescription components of bean pastes in the production environment

\section{RESULTS AND DISCUSSION}

It is revealed that the health transformation of future generations will depend on their way of life and the key position in this is occupied by nutrition (Electronic resource, 2018). Virtually erased boundaries (Ladodo et al., 2009) that define ethnic traditions of food consumption, which were formed over the centuries under the influence of natural conditions, historical, religious and social, and economic factors.

The spread of bean paste is unusual because we are all used to seeing beans in first and second courses and salty. To use beans as the main ingredient of a sweet recipe, in our opinion, not much can be imagined. And yet half of the world's inhabitants use this legume as a sweet dessert.

The works of the authors (Honda et al., 2020; Li et al., 2017; Balia, 2013) reflect the use of beans by Eastern countries as a sweet filling for many of their dishes. Beans are used in these countries to make Anko paste.

Table 3 Complex rheological indicator of the consistency of bean pastes with DDW.

\begin{tabular}{lcccc}
\hline \multirow{3}{*}{ Samples } & \multicolumn{4}{c}{ Meaning } \\
\cline { 2 - 5 } & Forming capacity & Strength & Elongation & Complex index \\
\cline { 2 - 5 } & Y $_{\mathbf{1}}$ & Y2 & Y3 & Y \\
\hline CPC & 0.40 & 0.20 & 0.40 & $\mathrm{Y}_{\mathrm{cpc}}=0.4 \mathrm{Y}_{1}+0.2 \mathrm{Y}_{2}+0.4 \mathrm{Y}_{3}$ \\
$\mathrm{CPD}$ & 0.15 & 0.15 & 0.7 & $\mathrm{Y}_{\mathrm{cpd}}=0.15 \mathrm{Y}_{1}+0.15 \mathrm{Y}_{2}+0.7 \mathrm{Y}_{3}$ \\
$\mathrm{FPM}$ & 0.60 & 0.25 & 0.15 & $\mathrm{Y}_{\mathrm{fpm}}=0.6 \mathrm{Y}_{1}+0.25 \mathrm{Y}_{2}+0.15 \mathrm{Y}_{3}$ \\
\hline
\end{tabular}

Note: $\mathrm{x}_{2}-\mathrm{DDW}$ content, \%; $\mathrm{Y}_{\mathrm{CPC}}$ - complex rheological indicator for legume paste CPC, points; Y Y rheological indicator for legume paste FPM, points; YCPD-complex rheological indicator for legume paste CPD, points.

Table 4 Levels and intervals of variation of factors of the complex rheological index of consistency of bean paste with DDW.

\begin{tabular}{|c|c|c|c|c|c|}
\hline \multirow[b]{2}{*}{ Factors } & \multirow[b]{2}{*}{ Code symbols } & \multirow[b]{2}{*}{$\begin{array}{c}\text { Intervals of } \\
\text { variation }\end{array}$} & \multicolumn{3}{|c|}{ Factors levels } \\
\hline & & & Main (0) & Upper (+1) & $\begin{array}{c}\text { Lower } \\
(-1)\end{array}$ \\
\hline Cocoa oil, $\%$ & $\mathrm{X}_{1}$ & 4 & 10 & 20 & 0 \\
\hline DDW content, $\%$ & $\mathrm{X}_{2}$ & 5 & 20 & 40 & 0 \\
\hline
\end{tabular}

Table 5 Parameters for optimizing the recipe components of legume butter.

\begin{tabular}{lccccccc}
\hline \multirow{2}{*}{ Samples } & \multicolumn{3}{c}{ Coconut oil, \% } & \multicolumn{2}{c}{ DDW, \% } \\
\cline { 2 - 7 } & $\begin{array}{c}\text { Minimum } \\
\text { value }\end{array}$ & $\begin{array}{c}\text { Maximum } \\
\text { value }\end{array}$ & $\begin{array}{c}\text { Optimal } \\
\text { value }\end{array}$ & $\begin{array}{c}\text { Minimum } \\
\text { value }\end{array}$ & $\begin{array}{c}\text { Maximum } \\
\text { value }\end{array}$ & $\begin{array}{c}\text { Optimal } \\
\text { value }\end{array}$ \\
\hline CPC & 9.8 & 10.3 & 10.0 & 19.4 & 22.5 & 20.0 \\
CPD & 9.7 & 10.1 & 10.0 & 9.8 & 10.5 & 10.0 \\
FPM & 9.8 & 10.2 & 10.0 & 29.4 & 31.1 & 30.0 \\
\hline
\end{tabular}


The longest and most difficult moment in the process of preparing Anko pasta is the preparation of the main ingredient which is beans. Since the beans are dried, they must be soaked in water for at least twelve hours. We soak the tested beans in water for at least $6-8$ hours. During this time, they increased in size and became quite soft.

In their research (Kravchenko and Rybchuk, 2019a; Kravchenko, and Rybchuk, 2019b) reveal the process of preparation of bean paste and its structural and mechanical properties. They note that cooking is as simple as possible, and most importantly, it includes a minimum amount of ingredients. Studies do not mention the effect of sugar on the structure and its amount.

The preparation and use of bean paste are presented by the authors (Chen et al., 2012; Gagarina, 2006), where it is given as a filling in other desserts, such as daifuku Moti, or as a filling in sweet pies, as is done in Japan, China. and other related states.

In the works (Krylova, 2000; Savenkova, 2012; Kuznetsova and Sydanova, 2002) the possibility of using the foaming properties of legumes is substantiated. Their research is aimed at the technology of cheese desserts based on the study of the range and technological properties of dessert's whipped structure. The chemical composition of peas and beans was analyzed (Sichkar, 2004), but the process of structure formation was not presented. The composition and structure of legume cells and the physical state of polymers have not been determined.

Studies (Arseneva, 2007) have established the influence of technological factors on the foaming properties of bean systems. It is established (Gagarina, 2006; Bachinska, 2017) that the optimal foaming properties of bean systems will be at hydro module $1: 20$; beating temperature $35^{\circ} \mathrm{C}$; duration 10 minutes; soaking beans - for 6 hours; cooking time 10 minutes Our data on the preparation of bean paste differ significantly.

There are food technologies using legume properties like foams. However, their foaming and properties remain unexplored. Little information about the change in taste properties The modern use of beans and raw milk in the technology of dessert production is limited. This gave impetus to the development of a new recipe and research on the use of beans.

Based on the developed technology and optimization of the recipe composition of legume butter, for the first time, we performed rheological and sensory studies aimed at substantiation of the features when using them. The effect of the DDW concentration on the adhesion strength of model compositions of legume butter was experimentally studied.

Studies of the dependence of the adhesion strength indicators made it possible to establish an increase in this indicator by $1.5-2$ times compared to the control. The analysis data are confirmed by the results of organoleptic consistency analysis, as evidenced by a significant increase in stickiness. This leads to difficulties in work with this type of developed pastes. Taking into consideration that bean butter has a similar versatility of use to the marzipan one in confectionery production (Stadnyk et al., 2020), it was considered appropriate to bring the adhesion strength indicators of bean butter with DDW closer to marzipan butter made using traditional techniques. Since bean butter is characterized by lower strength compared to marzipan butter, coconut oil was considered a promising component. It is conditioned by certain crystallization properties.

\section{The effect of coconut oil on organoleptic and structural- mechanical properties of model compositions of legume butter with dry demineralized whey.}

To determine the rational concentration of coconut oil in the recipe composition of legume butter with MSSD, model compositions have been developed. The effect of coconut oil on the organoleptic parameters of the model compositions of legume butter with DDW was determined following the developed score scale and presented in (Table 6).

According to the results of the analysis, a decrease in the stickiness of the model compositions of legume pastes CPC, CPD, FPM with an increase in the concentration of coconut oil was confirmed. Coconut oil helps to increase strength and density and gradually reduce extensibility indicators.

The result of organoleptic analysis of the consistency indicators of the model compositions of legume butter with DDW showed the best indicators at a coconut oil concentration of $10 \%$. The overall score according to the developed descriptors was 2.98 for CPC, 2.92 for CPD, and 2.95 for FPM.

To confirm organoleptic parameters, experimental studies of the effect of coconut oil concentration in the amount of $4-12 \%$ on the adhesion strength indicators of the model compositions of legume butter with DDW concentration were conducted.

With an increase in the concentration of coconut oil, the adhesion strength indicators of legume pastes decrease from 64.4 to $23.3 \mathrm{~N} . \mathrm{m}^{-2}$ at the DDW concentration of $20 \%$, from 55.7 to $21.8 \mathrm{~N} . \mathrm{m}^{-2}$ at the DDW concentration of $10 \%$,

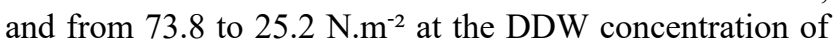
$30 \%$. As a result of the regularities analysis of the effect of coconut oil on the adhesion strength of legume butter with DDW, a decrease in this indicator was found to be up to 3 times compared to the corresponding control samples. Experimental studies have shown that $10 \%$ of coconut oil in the formula of legume butter with DDW allows bringing the adhesion strength closer to the indicators of marzipan butter made using traditional techniques. The effect of coconut oil concentration on the relative deformation indicators of the corresponding control samples. Experimental studies have shown that $10 \%$ of coconut oil in the formula of legume butter with DDW allows bringing the adhesion strength closer to the indicators of marzipan butter made using traditional technology. The effect of coconut oil concentration on the relative deformation indicators of the model compositions of legume butter with DDW was determined. The results of studies of the effect of coconut oil concentration on the deformation characteristics of the model compositions of legume butter with DDW are presented in Table 7. 
Table 6 Organoleptic characteristics of model compositions of legume butter with DDW and coconut oil.

\begin{tabular}{|c|c|c|c|c|c|c|c|c|c|}
\hline \multirow[t]{2}{*}{$\begin{array}{c}\text { Indicator } \\
\text { name }\end{array}$} & \multirow[t]{2}{*}{$\begin{array}{l}\text { Weighting } \\
\text { coefficient }\end{array}$} & \multirow[t]{2}{*}{ Characteristics } & \multirow[t]{2}{*}{$\begin{array}{c}\text { Descr. } \\
\text { number }\end{array}$} & \multirow[t]{2}{*}{$\begin{array}{l}\text { Weighting } \\
\text { coefficient }\end{array}$} & \multicolumn{5}{|c|}{$\begin{array}{c}\text { Samples with the addition of } \\
\text { coconut oil, } \%\end{array}$} \\
\hline & & & & & 4 & 6 & 8 & 10 & 12 \\
\hline \multicolumn{10}{|c|}{ CPC bean butter } \\
\hline \multirow{4}{*}{ Consistence } & \multirow{4}{*}{0.4} & $\begin{array}{l}\text { Density, } \\
\text { strength }\end{array}$ & 1 & 0.1 & 5.0 & 5.0 & 5.0 & 5.0 & 4.6 \\
\hline & & Stickiness & 2 & 0.1 & 4.4 & 4.6 & 4.8 & 5.0 & 5.0 \\
\hline & & Softness & 3 & 0.1 & 4.4 & 4.6 & 4.8 & 5.0 & 5.0 \\
\hline & & Extensibility & 4 & 0.7 & 5.0 & 5.0 & 5.0 & 4.8 & 4.2 \\
\hline \multicolumn{5}{|c|}{ The total score for CPC descriptors } & 4.88 & 4.92 & 4.96 & 4.93 & 4.4 \\
\hline \multicolumn{5}{|c|}{ The final assessment of the CPC indicator } & 1.95 & 1.96 & 1.98 & 1.93 & 1.76 \\
\hline Forming ability & 0.2 & $\begin{array}{l}\text { Detection } \\
\text { degree }\end{array}$ & 1 & 1.0 & 5.0 & 5.0 & 5.0 & 5.0 & 5.0 \\
\hline \multicolumn{5}{|c|}{ The total score for CPC descriptors } & 5.0 & 5.0 & 5.0 & 5.0 & 5.0 \\
\hline \multicolumn{5}{|c|}{ The final assessment of the CPC indicator } & 1.0 & 1.0 & 1.0 & 1.0 & 1.0 \\
\hline \multicolumn{5}{|c|}{ Overall CPC rating } & 2.95 & 2.95 & 2.98 & 2.98 & 2.76 \\
\hline \multicolumn{10}{|c|}{ CPD bean butter } \\
\hline \multirow[t]{4}{*}{ Consistence } & \multirow{4}{*}{0.3} & $\begin{array}{l}\text { Density, } \\
\text { strength }\end{array}$ & 1 & 0.2 & 4.6 & 4.8 & 5.0 & 5.0 & 3.8 \\
\hline & & Stickiness & 2 & 0.3 & 4.4 & 4.6 & 4.8 & 5.0 & 5.0 \\
\hline & & Softness & 3 & 0.2 & 4.4 & 4.6 & 4.8 & 5.0 & 3.8 \\
\hline & & Extensibility & 4 & 0.3 & 4.4 & 4.4 & 4.2 & 4.2 & 4.0 \\
\hline \multicolumn{5}{|c|}{ Total score by CPDdescriptors } & 4.44 & 4.58 & 4.66 & 4.76 & 4.22 \\
\hline \multicolumn{5}{|c|}{ The final assessment of the CPD indicator } & 1.33 & 1.37 & 1.39 & 1.42 & 1.26 \\
\hline Forming ability & 0.3 & $\begin{array}{l}\text { Detection } \\
\text { degree }\end{array}$ & 1 & 1.0 & 5.0 & 5.0 & 5.0 & 5.0 & 5.0 \\
\hline \multicolumn{5}{|c|}{ Total score by CPD descriptors } & 5.0 & 5.0 & 5.0 & 5.0 & 5.0 \\
\hline \multicolumn{5}{|c|}{ The final assessment of the CPD indicator } & 1.5 & 1.5 & 1.5 & 1.5 & 1.5 \\
\hline \multicolumn{5}{|c|}{ The general assessment of the CPD } & 2.83 & 2.87 & 2.89 & 2.92 & 2.76 \\
\hline \multicolumn{10}{|c|}{ Bean butter FPM } \\
\hline \multirow[t]{4}{*}{ Consistence } & & $\begin{array}{l}\text { Density, } \\
\text { strength }\end{array}$ & 1 & 0.3 & 5.0 & 5.0 & 4.8 & 4.8 & 3.8 \\
\hline & 0.2 & Stickiness & 2 & 0.3 & 4.4 & 4.6 & 4.8 & 5.0 & 5.0 \\
\hline & & Softness & 3 & 0.2 & 4.6 & 4.8 & 5.0 & 5.0 & 3.8 \\
\hline & & Extensibility & 4 & 0.2 & 4.4 & 4.4 & 4.2 & 4.2 & 4.0 \\
\hline \multicolumn{5}{|c|}{ The total estimate for FPM descriptors } & 4.12 & 4.72 & 7.72 & 4.78 & 4.2 \\
\hline \multicolumn{5}{|c|}{ The final assessment of the FPM indicator } & 0.82 & 0.84 & 0.94 & 0.95 & 0.84 \\
\hline Forming ability & 0.4 & $\begin{array}{l}\text { Detection } \\
\text { degree }\end{array}$ & 1 & 1.0 & 5.0 & 5.0 & 5.0 & 5.0 & 5.0 \\
\hline \multicolumn{5}{|c|}{ The total estimate for FPM descriptors } & 5.0 & 5.0 & 5.0 & 5.0 & 5.0 \\
\hline The final assessm & of the FPM & dicator & & & 2.0 & 2.0 & 2.0 & 2.0 & 2.0 \\
\hline Overall assessme & of the FPM & & & & 2.82 & 2.84 & 2.94 & 2.95 & 2.84 \\
\hline
\end{tabular}

Table 7 Deformation characteristics of the model compositions of legume butter with DDW and coconut oil.

\begin{tabular}{|c|c|c|c|c|c|c|c|c|}
\hline \multirow{2}{*}{ Indicator name } & \multirow{2}{*}{\multicolumn{2}{|c|}{ Designation }} & \multicolumn{6}{|c|}{ Samples with coconut oil addition, $\%$} \\
\hline & & & $\mathbf{0}$ & 4 & 6 & 8 & 10 & 12 \\
\hline \multirow{3}{*}{ Reversible deformation, $10^{-3}$} & \multirow{3}{*}{$\gamma_{\mathrm{sv}}$} & $\mathrm{CPC}$ & 340.0 & 325.7 & 302.9 & 301.0 & 287.1 & 281.4 \\
\hline & & CPD & 358.6 & 348.6 & 337.1 & 328.6 & 305.2 & 291.1 \\
\hline & & FPM & 334.3 & 328.1 & 312.9 & 305.0 & 289.1 & 276.4 \\
\hline Irreversible deformation, $10^{-3}$ & $\gamma_{\text {irrev }}$ & $\begin{array}{l}\text { CPC } \\
\text { CPD } \\
\text { FPM }\end{array}$ & 12.9 & 12.9 & 12.9 & 12.9 & 12.9 & 12.9 \\
\hline \multirow{3}{*}{ General deformation, $10^{-3}$} & \multirow{3}{*}{$\gamma_{\text {gen }}$} & $\mathrm{CPC}$ & 352.9 & 338.6 & 325.7 & 319.9 & 311.0 & 294.3 \\
\hline & & $\mathrm{CPD}$ & 371.4 & 361.4 & 350.0 & 341.4 & 320.0 & 300.1 \\
\hline & & FPM & 347.1 & 337.1 & 315.7 & 312.9 & 304.2 & 277.3 \\
\hline
\end{tabular}

Note: $(\mathrm{n}=5 ; p \leq 0.05)$. 
An increase in the concentration of coconut oil in the recipe composition of legume butter contributes to a gradual reduction in overall deformation by $25-30 \%$ compared to the control. The irreversible deformation is stable for all prototypes, does not depend on the DDW concentration, and is equal to 12.9 notional units. The reversible deformation decreases parallelly to the general strain values.

Accordingly, the reversible deformation indicators of the CPD decrease from 358.6 to 291.1 notional units, CPCfrom 340.0 to 281.4 notional units, FPM-334.3-276.4 notional units. The data obtained confirm the significant effect of coconut oil on the consistency of bean butter with DDW.

Features of the effect of coconut oil on the consistency of legume butter with DDW and conditions for achieving rational rheological parameters can be predicted by structural and mechanical characteristics. Clarification of the role of legume butter with DDW and coconut oil was carried out by setting up computational experiments to obtain the corresponding regression equations for the highly elastic modulus, conditionally instantaneous elastic modulus, pliability, and elastic aftereffect viscosity of the model compositions.

Based on the results of deformation characteristics, the main structural and mechanical characteristics of the coconut oil concentration range were determined. Mathematical dependences of the main structural and mechanical parameters of legume butter with DDW and coconut oil are determined in the form of:

\section{- Highly elastic module of the model compositions} $D D W 10 \% y=0.0315 x^{3}-0.64 x^{2}-2.1596 x+198.11$

when $R^{2}=0.9998$

$D D W 20 \% y=0.0923 x^{3}-1.5519 x^{2}+0.1525 x+190.75$

when $R^{2}=0.9944$

DDW $30 \% y=0.1002^{3}-1.7972 x^{2}+1.7426 x+184.67$

when $\mathrm{R}^{2}=0.9911$

- Conditionally instantaneous elastic modulus of the model compositions

$D D W 10 \% y=-0.00236 x^{3}-0.023 x^{2}-4.196 x+317.64$

when $R^{2}=0.9992$

$D D W 20 \% y=-0.003 x^{3}-0.0656 x^{2}-5.3025 x+312.99$

when $R^{2}=0.9963$

$D D W 30 \% y=0.0528 x^{3}-1.1029 x^{2}+1.0276 x+294.54$

when $R^{2}=0.9929$

\section{- Pliability of the model compositions}

$D D W 10 \% y=-0.1581 x^{3}+2.0264 x^{2}-11.787 x+874.21$

when $R^{2}=0.9932$

DDW $20 \% y=0.375 x^{3}-6.3333 x^{2}+11.25 x+829.85$

when $R^{2}=0.9993$

DDW $30 \%$ y $=0.111 x^{3}-1.9884 x^{2}-3.5323 x+817.09$

when $R^{2}=0.9934$

- Elastic aftereffect viscosity of the model compositions

DDW $10 \%$ y $=-0.005 x^{3}+0.041 x^{2}-1.099 x+12.46$

when $R^{2}=0.954$

$D D W 20 \% y=0.0368 x^{3}-0.6149 x^{2}-2.092 x+388.15$

when $R^{2}=0.9992$

$D D W 30 \% y=0.0513^{3}-0.9526 x^{2}+0.392 x+364.28$

when $R^{2}=0.9969$

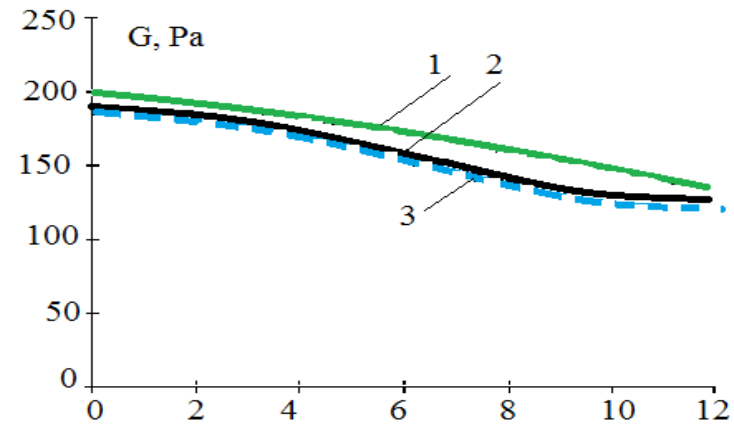

Figure 3 Highly elastic modulus of the model compositions of legume butter with DDW and coconut oil: 1 - DDW 10\%; 2 - DDW 20\%; 3 - DDW 30\%.

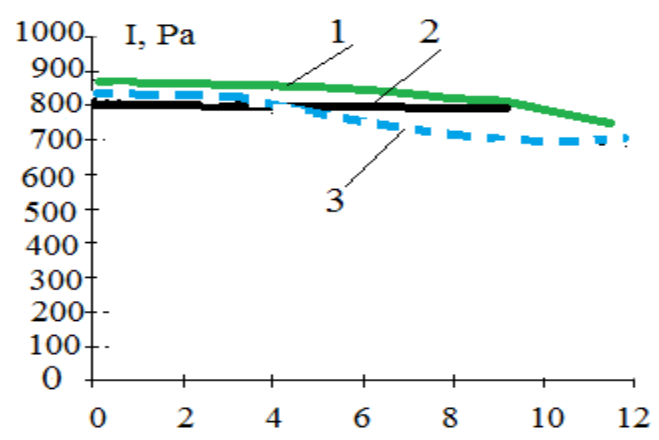

Figure 4 The pliability of the model compositions of legume butter with DDW and coconut oil: 1 - DDW 10\%; 2 - DDW 20\%; 3 - DDW 30\%.

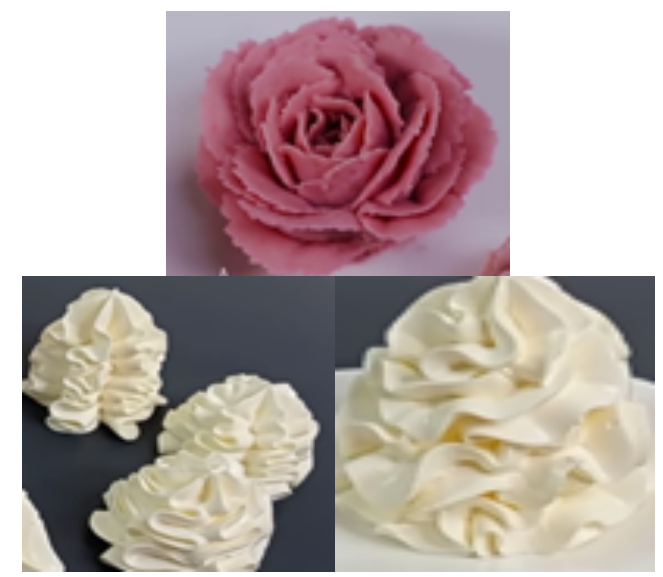

Figure 5 The products of model compositions.

Graphical dependences of the highly elastic modulus and pliability of the model compositions of legume butter with DDW and coconut oil are shown in Figure 3 and Figure 4.

With an increase in the concentration of coconut oil, the highly elastic modulus indicators $(\mathrm{Gel})$ decrease by 1.5 times, amounting to $198.1-134.4 \mathrm{~Pa}$ for CPC, $190.5-$ 128.2 Pa for CPD, and 184.5 - 120.1 PA for FPM (Figure. 2). It was found that the following elastic modulus indicators $\left(G_{\mathrm{pr}}\right)$, which are $313.2-254.2 \mathrm{~Pa}$ for CPC, 317.7 - 260.2 Pa for SC, and 296.3 - 240.1 Pa for FPM, decrease by 1.2 times. Elastic aftereffect viscosity, which is 381.2 - 341.1 $\mathrm{Pa} \cdot \mathrm{c}$ for CPD, 372.8 - 338.1 Pa $\mathrm{C}$ for CPC, $353.5-320.2 \mathrm{~Pa} \cdot \mathrm{c}$ for FPM, pliability $(\mathrm{I})$, which is $7.96-$ 
$7.5310^{-4} \mathrm{~Pa}^{-3}$ for CPC, $8.50-7.5010^{-4} \mathrm{~Pa}^{-3}$ for CPD, 7.80 $-6.81 \cdot 10^{-4} \mathrm{~Pa}^{-3}$ for FPM (Figure 3).

When compared with other plastic confectionery masses used as finishing semi-finished products, the developed legume butter has significant advantages. Based on research (Kravchenko and Rybchuk, 2019), it was found that the food energy of the developed confectionery legume butter is 2.7 times lower than that of sugar butter and 4.1 times lower than that of marzipan butter.

\section{CONCLUSION}

The developed technology of confectionery legume butter based on DDW makes it possible to obtain highquality low-calorie finishing semi-finished products for confectionery products. Results of the study confirm their high nutritional and biological value. A gradual decrease in the indicators of modular constants improves the forming ability, which ensures high processability of butter and is consistent with the results of the organoleptic analysis. According to the results of previous studies, the prospects of using DDW in legume butter technologies at a concentration of $10-30 \%$ and coconut oil at a concentration of $10 \%$ (Figure 5). Were confirmed, which makes it possible to obtain the desired structural and mechanical properties for finishing semi-finished products following the direction of their technological use.

\section{REFERENCES}

Arseneva, T. P., Baranova, Y. V. 2007. Osnovnye veshchestva dlia obohashchenyia produktov pytanyia (Essential Substances for Eating Foods). Pyshchevaia promyshlennost, vol. 1, p. 6-8.

Avdeyeva, L. Y. 2003. Improvement of the technology of combined meat products with vegetable proteins : dissertation theses. Kiev, Ukraine, 234 p.

Bachinska, J. 2017. The Use of Alternative Raw Material in Production of Pastry Products as a Progressive Direction in Creating the Products of High Biological ValuePath of Science. International Electronic Scientific Journal, vol.3, no. 2, p. 71-79.

Balia, L. V. 2011. Commodity science characteristics of white grain beans. Progressive technology and technologies offood production, restaurant and hotel economy and trade. Economic strategy and prospects for the development of trade and services, p. 3.

Balia, L. V. 2013. Improving the quality of canned beans in the fruit and vegetable sauce : dissertation theses. Kharkov, Ukraine, $19 \mathrm{p}$.

Chen, R. C-Y., Lee, M-S., Chang, Y-H., Wahlqvist, M. L. 2012. Cooking fre-quency may enhance survival in Taiwanese elderly. Public Health Nutr., vol. 15, no. 7, p. 1142-1149. https://doi.org/10.1017/S136898001200136X

Diakonova, A. K. 2006. Technological aspects of legume grain processing. Storage and processing of grain, vol. 2, no. 80, p. $28-29$.

DSTU 4803. 2013. Cakes and pastries general specifications, $23 \mathrm{p}$.

Dzjuba, O. M., Pazynych, L. M., Sytenko, O. R., Kryvenko, J. M. 2017. Shhodo pytannja global'nogo tjagarja hvorob v Ukrai'ni (On the issue of the global burden of disease in Ukraine). Visnyk social'noi' gigijeny ta organizacii' ohorony zdorov'ja Ukrai'ny - Bulletin of social hygiene and health care organization of Ukraine, vol. 72, no. 2, p.814-818. (in Ukrainian)
Electronic resource. 2018. Desiat tysiach krokiv do medytsyny maibutnoho (Ten thousand steps to the medicine of the future). Available at: http://stimul.online/viewpoint/. (in Russian)

Gagarina, Y. N. 2006. Belkovyi kompleks semian fasoly y yspytanye byolohycheskoi aktyvnosty eho komponentov (Bean Seed Protein Complex and Testing of Belonic Activity of Echo Components) : dissertation theses. Orel, Russia, 23 p. (in Russian)

GOST 5897-90. 1992. Confectionery. Methods for determining organoleptic indicators of quality, size, net weight and components.

GOST 5900-73. Confectionery. Methods for determination of moisture and dry matter.

Honda, Y., Saito, Y., Mishima, T., Katsumi, N., Matsumoto, K., Enomoto, T., Miwa, S. 2020. Characterization o physicochemical and digestive properties of starches from various "dainagon" adzuki beans (Vigna angularis) cultivated in Japan. International Journal of Biological Macromolecules, vol. 1, no. 26, p. 121-128. https://doi.org/10.1016/j.ijbiomac.2020.01.145

Kholodova, K. 2013. Improving the quality of sausage products through the use of leguminous raw materials : dissertation theses. Kharkiv, Ukraine : Kharkiv State University of Food Technology and Trade, p. 141-149.

Kozlova, O. 2014. A Study of Properties of StructureStabilizing Agents for Products Based on Dairy Raw Materials. Foods and Raw Materials, vol. 2, no. 2, p. 16-25. https://doi.org/10.12737/5455.

Kravchenko, M. F., Rybchuk, L. A. 2019b. Optymizacija himichnogo skladu marcypanovyh past [Optimization of the chemical composition of marzipan pastes]. Praci Tavrijs'kogo derzhavnogo agrotehnologichnogo universytetu Proceedings of the Tavriya State Agrotechnological University, vol. 3, no. 19, p. 233-240. (in Ukrainian)

Kravchenko, M. F., Rybchuk, L. A. 2019a. Novi vydy ozdobljuval'nyh kondyters'kyh napivfabrykativ (New types of finishing confectionery semi-finished products). Praci Tavrijs'kogo derzhavnogo agrotehnologichnogo universytetu - Proceedings of the Tavriya State Agrotechnological University, vol. 3, no. 19, p. 255-271. (in Ukrainian).

Kravchenko, M. F., Shapoval, S. L., Rybchuk, L. A. 2018. Surface properties of sugar pastes. Intern. Sci - Pract. Journal Goods and Markets, vol. 4, no. 28, p. 124-131.

Krylova, E. N. 2000. Netradytsyonnye vydy syria dlia kondyterskykh yzdelyi lechebno-profylaktycheskoho naznachenyia (Non-traditional types of Syria for confectionery treatment and prevention purposes). Pyshchevaia Promyshlennost, vol. 4, p. 61.

Kuznetsova, L. S., Sydanova, M. I. 2002. Tekhnolohyia pryhotovlenyia muchnykh kondyterskykh yzdelyi (Technology of preparation of flour confectionery). Masterstvo, $320 \mathrm{p}$.

Ladodo, K. S., Borovyk, T. E., Semenova, N. N., Surzhyk, A. V. 2009. Formyrovanye pravylnoho pyshchevoho povedenyia (Formation of proper eating behavior). Lechashchyi Vrach, vol. 1, p. 54-57.

Li, Z., Rui J., Li J., Dong L., Huang Q., Huang C. 2017. Bacterial community succession and metabolite changes during doubanjiang-meju fermentation, a Chinese traditional fermented broad bean (Vicia faba L.) paste. Food Chemistry, vol. 1, no. 218, p. 534-542. https://doi.org/10.1016/j.foodchem.2016.09.104

Lukomets, V. 2012. Soya: khimicheskiy sostav i ispolzovaniye (Soy: a chemical compound and use). Russia : Poligraf-Yug, Maykop, $432 \mathrm{p}$ 
Mazaraki, A. A., Kravchenko, M. F., Demichkovskaya, M. P. 2019. Mister Bean. Tasty Legume Dishes. Kiev, Ukraine : Trade economy University, $292 \mathrm{p}$.

Nazarova, O. Y., Chuprina, O. A. 2018. Modern state of confectionery production as a segment of the Food Industry. Economy and society. Mukachevo : Moscow State University, vol. 16, p. 42-49.

Ryabchenko, M. 2008. Chickpea as a valuable leguminous crop for food and fodder purposes. Ryabchenko, K. Ulyanchenko. Byul. Institute of The Grain Economy, p. 33-34.

Savenkova, T. V. 2012. Proyzvodstvo funktsyonalnykh kondyterskykh yzdelyi - problemy y puty ykh reshenyia (Production of functional confectionery - problems and solutions). Kondyterskoe y Khlebopekarnoe Proyzvodstvo, vol. 7, p. 6-7.

Sichkar, V. I. 2004. The role of legumes in solving the protein problem in Ukraine. Feed and feed production, p. 110-115.

Skurikhin, I. M., Volgarev, M. N. 1987. Khimicheskiy sostav pishchevych produktov (The chemical composition of food products). Moscow, Russia : Agropromizdat, p. 32-34.

Stadnyk, I., Novak, L., Matenchuk, L. 2018. Global rheological approach tothe quality of medium injected by the rollers. Potravinarstvo Slovak Journal for Food Sciences, vol. 12, no. 1, p. 397-404. https://doi.org/10.5219/867

Stadnyk, I., Piddubnuy, V., Kravchenko, M., Rybchuk, L., Kolomiiets, O., Danylo, S. 2020. Adhesion of marzipan pastes based on dry demineralized whey. Potravinarstvo Slovak Journal of Food Sciences, vol. 14, no. 1, p. 1149-1160. https://doi.org/10.5219/1351

Stadnyk, I., Piddubnyi, V., Karpyk, H., Kravchenko, M., Hidzhelitskyi, V. 2019. Adhesion effect on environment process injection. Potravinarstvo Slovak Journal for Food Sciences, vol. 13, no. 1, p. 429-437. https://doi.org/10.5219/1078.

WHO. 2015. Global health risk factors: mortality and disease burden due to some basic risk factors. Zheneva : VOZ. (in Russian).

\section{Funds:}

This research received no external funding.

\section{Acknowledgments:}

We would like to thank you to Prof. Dr. Igor Stadnyk.

\section{Conflict of Interest:}

The authors declare no conflict of interest.

\section{Ethical Statement:}

This article does not contain any studies that would require an ethical statement.

\section{Contact address:}

*Prof. Dr. Igor Stadnyk, Ternopil Ivan Puluj National Technical University, Department of Food Biotechnology and Chemistry, Ukraine, Ternopil 46001, Hohol str. 6, Tel.: +380975454829,

E-mail: igorstadnykk@gmail.com

ORCID: https://orcid.org/0000-0003-4126-3256

Prof. Dr. Volodymyr Piddubnyi, Kyiv National University of Trade and Economics, Faculty of Biotechnology and Food Sciences, Department of Technologies and Organization of Restaurant Business, Kyoto str. 19, Kyiv 02156, Ukraine, Tel.: +380674017096, E-mail: a.poddubnaya@i.ua

ORCID: https://orcid.org/0000-0001-8051-3743

Prof. Dr. Mykhail Kravchenko, Kyiv National University of Trade and Economics, Department of Technology and Restaurant Management Organization, Kyoto str. 19, Kyiv 02156, Ukraine, Tel.: +380973379745,

E-mail: m.f.kravchenko@gmail.com

ORCID: https://orcid.org/0000-0002-0093-2786

Larysa Rybchuk, Graduate student, Kyiv National University of Trade and Economics,Department of technology and the organization of restaurant business, Kyoto str., 19, Kiev 02156, Ukraine, Tel.: (097) 439-03-08 E-mail: lorchik88@ukr.net

ORCID: http://orcid.org/0000-0002-6282-7295

Stepan Balaban PhD., Ternopil Ivan Puluj National Technical University, Department of Food Biotechnology and Chemistry, Ukraine, Ternopil 46001, Hohol str. 6, Tel.: +380975454829,

E-mail: mukolabalaban@gmal.com

ORCID: https://orcid.org/0000-0001-6154-339x

Taisia Veselovska, Candidate of Techncal Scieces, Ph.D., Departament of Tourism and Hotel and Restaurant Business, Kamianets-Podilskyi Ivan Ohiienko National University, UKRAINE, 37/18 Pushkinskaya St. Kamianets-Podilskyi, Ukraine, 32316,

Tel.: +380676028178,

E-mail: kveta utei@ukr.net

ORCID: https://orcid.org/0000-0003-3300-7172

Corresponding author: * 